This item was submitted to Loughborough's Research Repository by the author.

Items in Figshare are protected by copyright, with all rights reserved, unless otherwise indicated.

\title{
Diffusion barrier property of electroless Ni-W-P coating in high temperature Zn-5Al/Cu solder interconnects
}

PLEASE CITE THE PUBLISHED VERSION

https://doi.org/10.1016/j.jallcom.2017.06.122

\section{PUBLISHER}

(C) Elsevier

\section{VERSION}

AM (Accepted Manuscript)

\section{PUBLISHER STATEMENT}

This work is made available according to the conditions of the Creative Commons Attribution-NonCommercialNoDerivatives 4.0 International (CC BY-NC-ND 4.0) licence. Full details of this licence are available at: https://creativecommons.org/licenses/by-nc-nd/4.0/

\section{LICENCE}

CC BY-NC-ND 4.0

\section{REPOSITORY RECORD}

Liu, Li, Zhiwen Chen, Zhaoxia Zhou, Guang Chen, Fengshun Wu, and Changqing Liu. 2019. "Diffusion Barrier Property of Electroless Ni-w-p Coating in High Temperature Zn-5al/cu Solder Interconnects". figshare. https://hdl.handle.net/2134/25511. 


\title{
Diffusion barrier property of electroless Ni-W-P coating in high temperature $\mathrm{Zn}-5 \mathrm{Al} /$ $\mathrm{Cu}$ solder interconnects
}

\author{
Li Liu ${ }^{\text {a, b }}$, Zhiwen Chen ${ }^{\text {a d,? }}$, Zhaoxia Zhou ${ }^{\mathrm{c}}$, Guang Chen ${ }^{\mathrm{b}, \mathrm{d}}$, Fengshun Wu ${ }^{\mathrm{d}}$, Changqing Liu ${ }^{\mathrm{b},}$ \\ a School of Materials Science and Engineering, Wuhan University of Technology, Wuhan, 430070, China \\ ${ }^{\mathrm{b}}$ Wolfson School of Mechanical, Electrical and Manufacturing Engineering, Loughborough University, Loughborough, Leicestershire, LE11 3TU, UK \\ ' Loughborough Materials Characterisation Centre, Loughborough University, Loughborough, Leicestershire, LE11 3TU, UK \\ d School of Materials Science and Engineering, Huazhong University of Science and Technology, Wuhan, 430074, China
}

\section{A R T I C L E I N F O}

Article history:

Received 14 February 2017

Accepted 11 June 2017

Available online $\mathrm{xxx}$

Keywords:

$\mathrm{Zn}-5 \mathrm{Al}$ solder

Electroless Ni-W-P coating

Diffusion barrier

Interfacial reaction

Kirkendall voids

\begin{abstract}
A B S T R A C T
The operating temperature of high-temperature electronics can significantly promote the growth of intermetallic compounds (IMCs) at solder/substrate interfaces, particularly for low-cost Zn-based solders because of the rapid rate of reaction of $\mathrm{Zn}$ with $\mathrm{Cu}$. Thus, a reliable and robust diffusion barrier is indispensable for suppressing the reactions between solder and substrate. In this work, a ternary Ni-W-P alloy was prepared via electroless plating. Its diffusion barrier property was evaluated by comparing the microstructures of IMC layers in $\mathrm{Zn}-5 \mathrm{Al} / \mathrm{Ni}-\mathrm{W}-\mathrm{P} / \mathrm{Cu}$ and $\mathrm{Zn}-5 \mathrm{Al} / \mathrm{Cu}$ interconnects after liquid-solid reaction for prolonged durations. When the reaction lasted for $30 \mathrm{~min}$, the thickness of the $\mathrm{Al}_{3} \mathrm{Ni}_{2}$ produced in the $\mathrm{Zn}-5 \mathrm{Al} / \mathrm{Ni}-\mathrm{W}-\mathrm{P} / \mathrm{Cu}$ solder interconnects was only $2.15 \mu \mathrm{m}$, whereas the thickness of the interfacial layer of $\mathrm{Cu}-\mathrm{Zn} \mathrm{IMCs}\left(\mathrm{CuZn}_{4}, \mathrm{Cu}_{5} \mathrm{Zn}_{8}\right.$ and $\mathrm{CuZn}$ ) at the $\mathrm{Zn}-5 \mathrm{Al} / \mathrm{Cu}$ interface was $94 \mu \mathrm{m}$. Because of the unbalanced growth of the IMCs in the $\mathrm{Zn}-5 \mathrm{Al} /$ $\mathrm{Cu}$ interconnects, notable numbers of Kirkendall voids were identified at the $\mathrm{CuZn} \mathrm{Zn}_{4} / \mathrm{Cu}_{5} \mathrm{Zn}_{8}, \mathrm{Cu}_{5} \mathrm{Zn}_{8} / \mathrm{CuZn}$ and $\mathrm{CuZn} / \mathrm{Cu}$ interfaces after prolonged liquid-solid reaction. By contrast, the $\mathrm{Al}_{3} \mathrm{Ni}_{2}$ layer in the $\mathrm{Zn}-5 \mathrm{Al} /$ $\mathrm{Ni}-\mathrm{W}-\mathrm{P} / \mathrm{Cu}$ solder joints remained intact, showing the potential to effectively enhance the mechanical reliability of electronic devices.
\end{abstract}

\section{Introduction}

High-lead solders ( $\mathrm{Pb}$ content: 85-97 wt.\%) are commonly applied in high-temperature electronics (HTE), including devices for use in aircraft, automotive, space and drilling applications $[1,2]$. However, due to health and environmental concerns, the development of high-temperature lead-free solders to replace lead solders is of vital importance. Recently, considerable research has been conducted on various high-temperature alternatives, including $\mathrm{Au}-\mathrm{rich}, \mathrm{Bi}-\mathrm{Ag}$, and $\mathrm{Zn}$-based solders as well as nano-silver paste. Unfortunately, certain notable drawbacks have limited their applications, such as the high cost of Au-rich solder [3], the low wettability and brittleness of Bi-Ag solder [4], and the high cost and porosity of nano-silver assemblies [5,6]. Among these alternatives, Zn-based solder is a potential lead-free candidate by virtue of its low cost, high melting point, and good thermal and electrical conductivity, and thus, this potential solder material deserves further investigation $[7,8]$.

However, $\mathrm{Zn}$-based solders actively react with $\mathrm{Cu}$ substrates to produce excessive $\mathrm{Cu}-\mathrm{Zn}$ intermetallic compounds (IMCs), particularly at elevated temperatures. This makes solder joints brittle and prone to fracture [9]. To solve this challenge, diffusion barriers can be utilised to hinder the interfacial reactions in $\mathrm{Zn}$-based solder

\footnotetext{
* Corresponding author.

Email address: C.Liu@lboro.ac.uk (C. Liu)
}

joints. In industry, electroless Ni-P coatings have been widely employed as diffusion barriers in conventional electronics. Unfortunately, this alloy is not suitable for HTE because of its low crystallisation temperature and weak thermal stability as well as the voids that form in a crystalline $\mathrm{Ni}_{3} \mathrm{P}$ layer [10-12]. Therefore, a reliable and robust diffusion barrier that functions stably is critically required for high-temperature solder joints, especially for $\mathrm{Zn}-5 \mathrm{Al}$ solder, a typical high-temperature solder. Previous works have reported that the incorporation of $\mathrm{W}$ can significantly retard the crystallisation of electroless Ni-P alloys [13-15]. Moreover, a few researchers have studied the reactions of Ni-W-P coatings with $\mathrm{Sn}-\mathrm{Bi}$ or $\mathrm{Sn}-3.5 \mathrm{Ag}$ solders, drawing the conclusion that the interfacial reactions with a Ni-W-P interlayer are clearly slower than those with a Ni-P interlayer [15-17]. However, these solders are generally applied in a relatively low-temperature regime (peak reflow temperature $<220^{\circ} \mathrm{C}$ ).

To date, the interfacial reactions between electroless Ni-W-P layers and high-temperature solders during reflow has seldom been reported. In this work, the effects of electroless Ni-W-P coatings on inhibiting the interfacial reactions in $\mathrm{Zn}-5 \mathrm{Al}$ solder interconnects were investigated in comparison with a bare $\mathrm{Cu}$ substrate. Attention was directed towards the reduction of the growth rates of interfacial IMC layers and the prevention of Kirkendall void formation at the solder/ substrate interface during liquid-solid reaction after the application of an electroless Ni-W-P coating. The morphological evolution of the IMCs at these interfaces was also investigated. 


\section{Experimental procedures}

\subsection{Electroless $\mathrm{Ni}-\mathrm{W}$-P plating}

An electroless Ni-W-P ternary alloy was produced on polycrystalline copper substrates. Prior to electroless plating, a pre-polished $\mathrm{Cu}$ sheet (99.9\% purity, $1 \mathrm{~mm}$ thickness) was cut into square pieces $(20 \times 20 \mathrm{~mm})$ and then ultrasonically cleaned with acetone followed by 50 vol. $\% \mathrm{HCl}$ acid to remove oil and oxidation, respectively. Next, these copper substrates were immersed in a plating bath, and an aluminium wire was subsequently attached to the copper surface to initiate deposition. The wire was then removed after the formation of an initial thin Ni-W-P layer. The plating solution was an alkaline bath consisting of deionised water and sodium tungstate $(7 \mathrm{~g} / \mathrm{L})$, nickel sulphate $(35 \mathrm{~g} / \mathrm{L})$, sodium hypophosphite $(12 \mathrm{~g} / \mathrm{L})$ and sodium acetate $(40 \mathrm{~g} / \mathrm{L})$. The plating temperature was $88 \pm 2{ }^{\circ} \mathrm{C}$, and the plating time was $30 \mathrm{~min}$. After deposition, all substrates were cleaned and dried for the preparation of the solder interconnects.

\subsection{Preparation of $\mathrm{Zn}-5 \mathrm{Al}$ solder interconnects}

Prior to reflow, $\mathrm{Zn}-5 \mathrm{Al}$ solder pellets (weight: approximately $0.15 \mathrm{~g}$, melting point: $382^{\circ} \mathrm{C}$ ) were placed on Ni-W-P-plated $\mathrm{Cu}$ substrates and bare $\mathrm{Cu}$ substrates for comparison. The reflow was conducted on a hotplate attached to a temperature control unit to perform

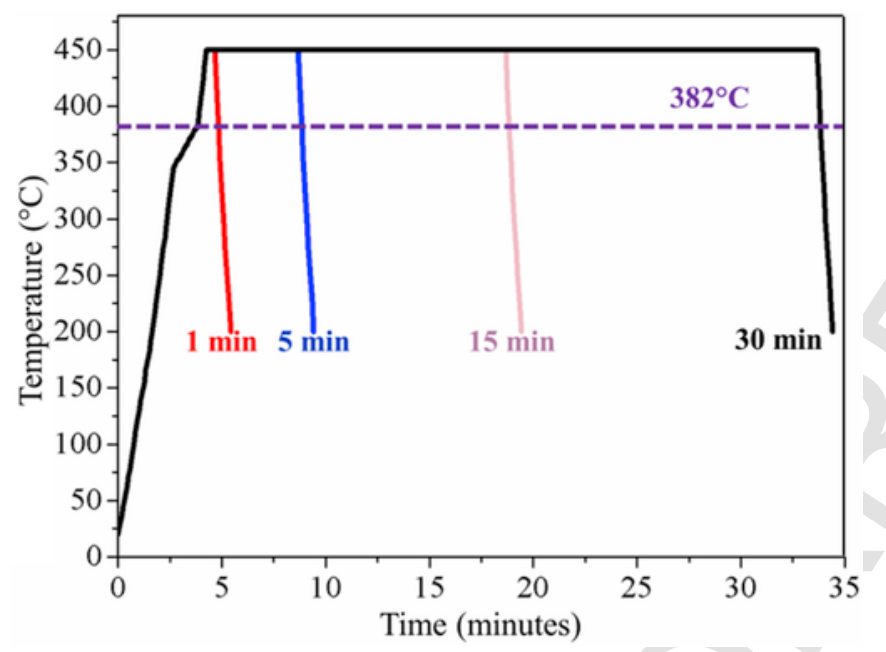

Fig. 1. Reflow temperature profiles of the $\mathrm{Zn}-5 \mathrm{Al}$ solder interconnects.

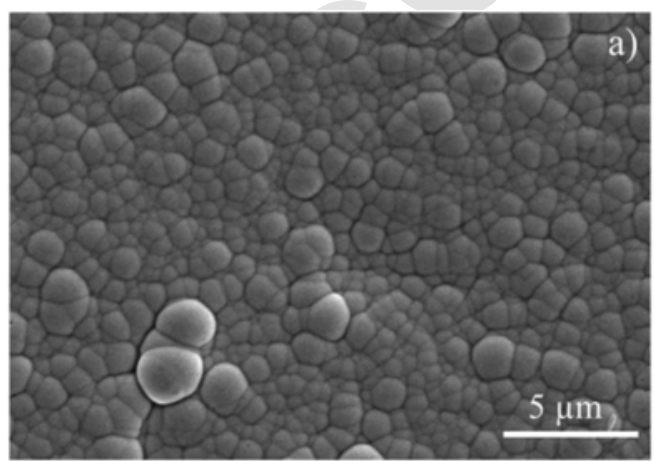

a reflow profile as shown in Fig. 1. A K-type thermal couple that measured real-time temperature of the samples validated the consistency with the pre-set temperature profile. The durations of reaction between the molten $\mathrm{Zn}-5 \mathrm{Al}$ solders and the solid $\mathrm{Cu}$ substrates ranged from 1 to $30 \mathrm{~min}$.

\subsection{Morphological and microstructural observations}

After reflow, some specimens were cold mounted, ground and finally polished using colloidal silica to reveal their cross-sectional microstructures. The microstructures of the interfacial IMCs that formed at the $\mathrm{Zn}-5 \mathrm{Al} / \mathrm{Cu}$ and $\mathrm{Zn}-5 \mathrm{Al} / \mathrm{Ni}-\mathrm{W}-\mathrm{P} / \mathrm{Cu}$ interfaces under the same reflow conditions were investigated using scanning electron microscopy (SEM, Zeiss 1530VP) combined with energy-dispersive $\mathrm{X}$-ray spectroscopy (EDS). The thicknesses of the Ni-W-P coatings and IMC layers were also measured using ImageJ software. Meanwhile, the top-view morphologies of the IMCs formed in the $\mathrm{Zn}-5 \mathrm{Al}$ / $\mathrm{Ni}-\mathrm{W}-\mathrm{P}$ solder interconnects were examined by etching the $\mathrm{Zn}-5 \mathrm{Al}$ solders with a dilute $\mathrm{NaOH}$ solution $(20 \mathrm{~g} / \mathrm{L})$.

\section{Results and discussion}

\subsection{As-deposited electroless $N$ i-W-P coating}

The as-deposited Ni-W-P coating consisted of 7-8 wt.\% $\mathrm{P}$ and $18-19$ wt.\% W, according to the EDX analysis. The surface morphology and cross section of this Ni-W-P coating are shown in Fig. 2. Its surface exhibited a typical cauliflower-like morphology with smooth nodules of uneven size (size range: $0.5-1.5 \mu \mathrm{m}$ ). No visible defects and pores were observed on its surface. As shown in Fig. 2 b), the thickness of the Ni-W-P coating was approximately $2 \mu \mathrm{m}$. Overall, this coating was free of cracks, compact and adherent, showing good properties as a barrier layer. It was firmly adhered to the $\mathrm{Cu}$ substrate, as no visible pores could be seen at the interface.

\subsection{Evolution of IMC morphologies during liquid-solid reaction}

The cross-sectional microstructures and corresponding topographies of the interfacial IMCs in $\mathrm{Zn}-5 \mathrm{Al} / \mathrm{Ni}-\mathrm{W}-\mathrm{P} / \mathrm{Cu}$ solder interconnects are shown in Fig. 3. According to their cross-sectional microstructures in Fig. 3a), c), e) and g), only one thin IMC layer formed at the $\mathrm{Zn}-5 \mathrm{Al} / \mathrm{Ni}-\mathrm{W}-\mathrm{P}$ interfaces, with a thickness that increased from 0.5 to $2.15 \mu \mathrm{m}$ as the liquid-solid reaction duration increased from 1 to $30 \mathrm{~min}$. To precisely identify this IMC layer, elemental analysis was performed on the $\mathrm{Zn}-5 \mathrm{Al} / \mathrm{Ni}-\mathrm{W}-\mathrm{P}$ solder interconnects subjected to the longest reaction time ( $30 \mathrm{~min}$ ), and the composition was identified as $\mathrm{Al}_{3} \mathrm{Ni}_{2}$, as presented in Fig. 4.

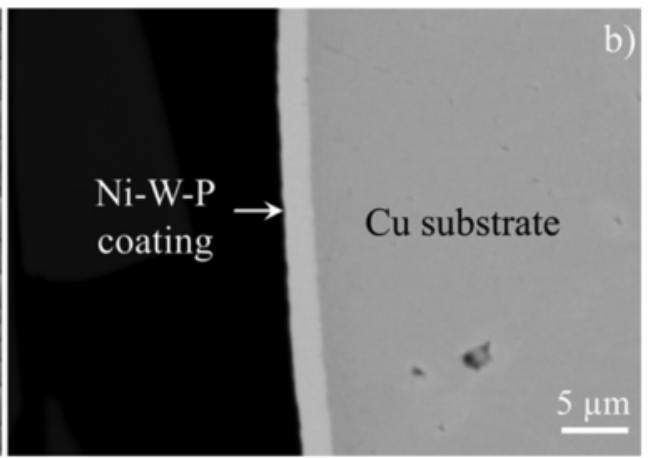

Fig. 2. Micrographs of an as-deposited Ni-W-P coating: a) surface morphology and b) cross-sectional morphology. 

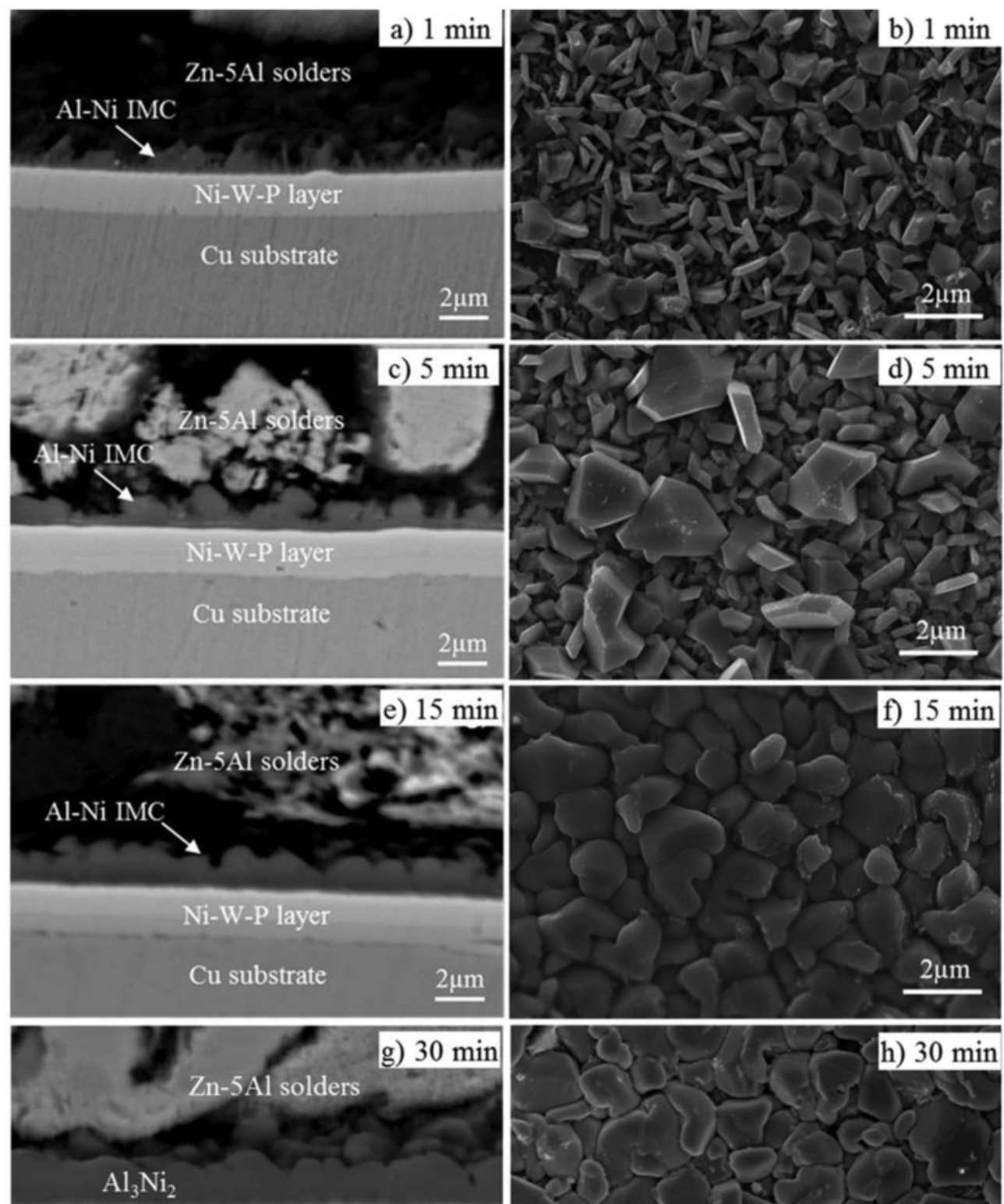

Ni-W-P layer

Cu substrate

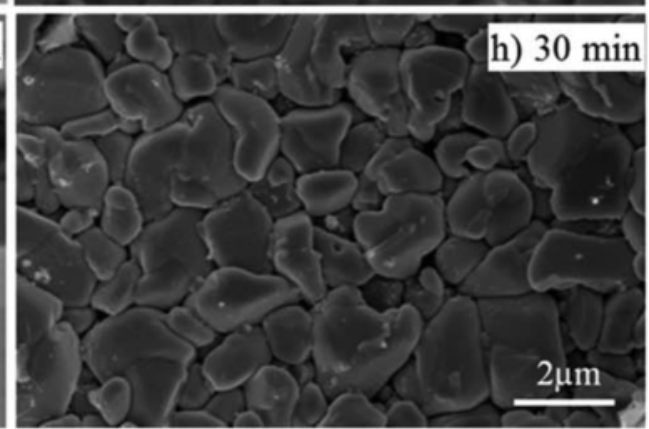

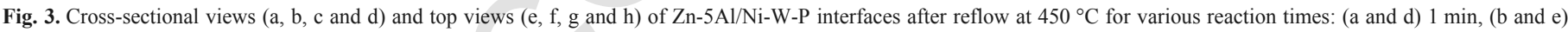
$5 \mathrm{~min}$, (c and f) $15 \mathrm{~min}$, and ( $\mathrm{g}$ and h) $30 \mathrm{~min}$.

Regarding the topography of the $\mathrm{Al}_{3} \mathrm{Ni}_{2}$, after 1 min of reaction, the generated $\mathrm{Al}_{3} \mathrm{Ni}_{2}(0.5 \mu \mathrm{m}$ in thickness $)$ exhibited prism-like or plate-like shapes, as shown in Fig. 3 b). As the reaction time increased to $5 \mathrm{~min}$, the average thickness of the $\mathrm{Al}_{3} \mathrm{Ni}_{2}$ layer grew to approximately $0.9 \mu \mathrm{m}$. The plate-like IMCs transformed into rod-like shapes, whereas the prism-like IMCs continuously grew to a larger size of approximately $2 \mu \mathrm{m}$ (Fig. $3 \mathrm{~d}$ ). After liquid-solid reaction for $15 \mathrm{~min}$, some of the larger $\mathrm{Al}_{3} \mathrm{Ni}_{2}$ grains (size: $\sim 2 \mu \mathrm{m}$ ) continued to grow into round scalloped shapes by merging with adjacent smaller $\mathrm{Al}_{3} \mathrm{Ni}_{2}$ grains (size: $\sim 0.2 \mu \mathrm{m}$ ), resulting in a continuous $\mathrm{Al}_{3} \mathrm{Ni}_{2}$ layer, as illustrated in Fig. 3 e). The size of these scalloped IMCs ranged from 1 to $2.1 \mu \mathrm{m}$. Finally, after $30 \mathrm{~min}$ of reaction, faceted scallops with a polygonal shape were observed, with a slightly increased grain size (up to $2.5 \mu \mathrm{m}$ ) as shown in Fig. $3 \mathrm{~h}$ ). Overall, the shapes of the $\mathrm{Al}_{3} \mathrm{Ni}_{2}$ grains transformed from initial prism-like or plate-like shapes into rod-like shapes and subsequently grew into scallop shapes.

From the elemental mapping results for this solder interface after 30 min of reaction (see Fig. 4), it is clear that $\mathrm{Ni}$ atoms in the Ni-W-P coating diffused out and reacted with Al atoms from the $\mathrm{Zn}-5 \mathrm{Al}$ solder to form $\mathrm{Al}_{3} \mathrm{Ni}_{2}$. By contrast, the signals from $\mathrm{Zn}$ and $\mathrm{Cu}$ were observed to terminate at the $\mathrm{Zn}-5 \mathrm{Al} / \mathrm{Al}_{3} \mathrm{Ni}_{2}$ and $\mathrm{Ni}-\mathrm{W}-\mathrm{P} / \mathrm{Cu}$ interfaces, respectively. This indicates that $\mathrm{Zn}$ and $\mathrm{Cu}$ atoms did not diffuse through the Ni-W-P interlayer, thereby demonstrating its excellent diffusion barrier property for eliminating the interdiffusion of 


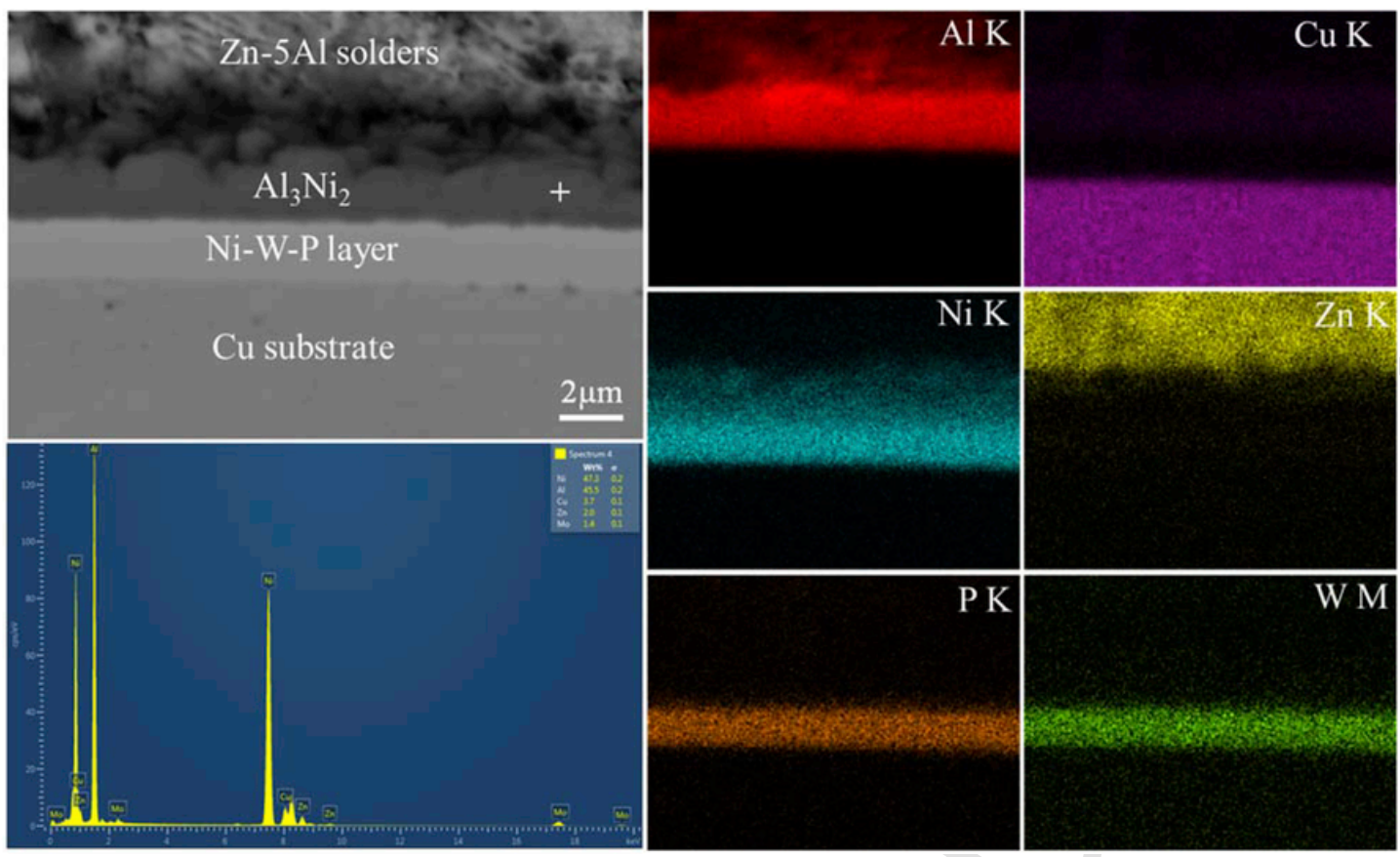

Fig. 4. Elemental mapping and pointing analysis of a $\mathrm{Zn}-5 \mathrm{Al} / \mathrm{Ni}-\mathrm{W}-\mathrm{P}$ interface after $30 \mathrm{~min}$ of liquid-solid reaction at $450{ }^{\circ} \mathrm{C}$.

$\mathrm{Zn}$ and $\mathrm{Cu}$. It has been reported that in $\mathrm{Zn}-4 \mathrm{Al} / \mathrm{Ni}$ solder interconnects, $\mathrm{Al}_{3} \mathrm{Ni}_{2}$ grains peel from the Ni substrate and disperse into the solder matrix to form a thick zone after $5 \mathrm{~min}$ of liquid-solid reaction at $450{ }^{\circ} \mathrm{C}[18]$. However, no spalling of the $\mathrm{Al}_{3} \mathrm{Ni}_{2}$ occurred in the $\mathrm{Zn}-5 \mathrm{Al} / \mathrm{Ni}-\mathrm{W}-\mathrm{P}$ system, even after liquid-solid reaction for up to 30 min at $450{ }^{\circ} \mathrm{C}$. This observation thus additionally confirms the excellent diffusion barrier property of an electroless Ni-W-P interlayer compared with a bare Ni substrate.
For $\mathrm{Zn}-5 \mathrm{Al}$ solder interconnects without a Ni-W-P interlayer, cross-sectional micrographs of the IMCs formed after liquid-solid reaction at $450{ }^{\circ} \mathrm{C}$ for up to $30 \mathrm{~min}$ are presented in Fig. 5. The compositions of these IMC phases are shown in Table 1. The thickness of the interfacial IMCs at the $\mathrm{Zn}-5 \mathrm{Al} / \mathrm{Cu}$ interface $(94 \mu \mathrm{m}, 30 \mathrm{~min}$ of reaction) was much higher than it was at the $\mathrm{Zn}-5 \mathrm{Al} / \mathrm{Ni}-\mathrm{W}-\mathrm{P}$ interface $(2.15 \mu \mathrm{m}, 30 \mathrm{~min}$ of reaction). Such a high IMC thickness could cause problems in interfacial integrity due to the brittle nature of IMCs and their mismatches with the physical properties (e.g., elastic

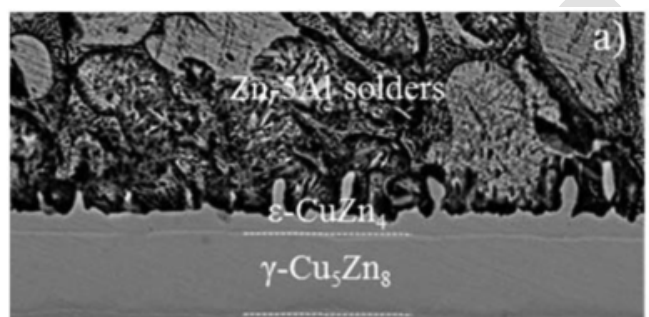

Cu substrate
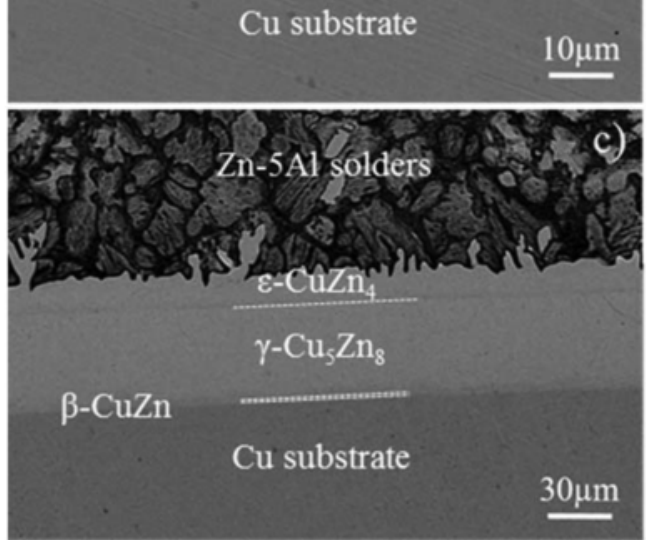

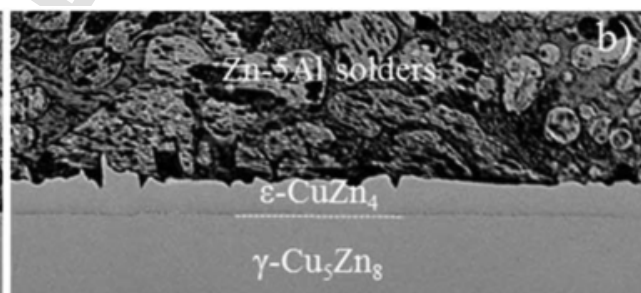

$\beta-C u Z n$

Cu substrate.

$15 \mu \mathrm{m}$

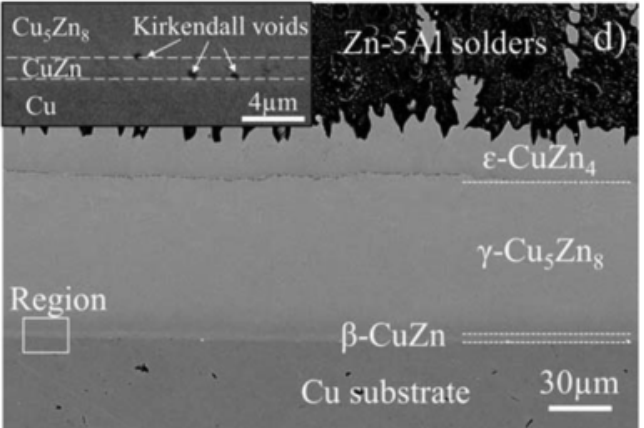

Fig. 5. Backscattered SEM images showing the IMCs formed at $\mathrm{Zn}-5 \mathrm{Al} / \mathrm{Cu}$ interfaces after liquid-solid reaction for a) $1 \mathrm{~min}$, b) $5 \mathrm{~min}$, c) $15 \mathrm{~min}$, and d) $30 \mathrm{~min}$. 
Table 1

Results of a quantitative EDX analysis of the IMCs formed at a $\mathrm{Zn}-5 \mathrm{Al} / \mathrm{Cu}$ interface

\begin{tabular}{llll}
\hline Position & $\begin{array}{l}\text { Cu composition } \\
\text { (at.\%) }\end{array}$ & $\begin{array}{l}\text { Zn composition } \\
\text { (at.\%) }\end{array}$ & $\begin{array}{l}\text { Corresponding } \\
\text { IMC }\end{array}$ \\
\hline $\begin{array}{l}\text { Upper layer } \\
\text { Medium } \\
\begin{array}{l}\text { layer } \\
\text { Lower layer }\end{array}\end{array}$ & 20.3 & 79.7 & $\varepsilon-\mathrm{CuZn}_{4}$ \\
& 52.3 & 60.9 & $\gamma-\mathrm{Cu}_{5} \mathrm{Zn}_{8}$ \\
\hline
\end{tabular}

moduli and coefficients of thermal expansion) of the solder and substrate [19-21].

After 1 min of reaction, the upper layer adjacent to the $\mathrm{Zn}-5 \mathrm{Al}$ solder was a dendritic $\varepsilon-\mathrm{CuZn}_{4}$ layer $(\sim 4 \mu \mathrm{m})$, whereas an interlayer of $\gamma-\mathrm{Cu}_{5} \mathrm{Zn}_{8}(\sim 12.5 \mu \mathrm{m})$ had formed between the $\mathrm{CuZn}_{4}$ and the $\mathrm{Cu}$ substrate. The activation energies for the formation of $\mathrm{CuZn}_{4}$ and $\mathrm{Cu}_{5} \mathrm{Zn}_{8}$ have been reported to be 29.54 and $42.38 \mathrm{~kJ} / \mathrm{mol}$, respectively [22]. Therefore, it can be inferred that $\mathrm{CuZn}_{4}$ was likely the first IMC to be produced at the $\mathrm{Zn} / \mathrm{Cu}$ interface, followed by the formation of $\mathrm{Cu}_{5} \mathrm{Zn}_{8}$. After 5 min of liquid-solid reaction, the thicknesses of the $\mathrm{CuZn}_{4}$ and $\mathrm{Cu}_{5} \mathrm{Zn}_{8}$ had grown to $8 \mu \mathrm{m}$ and $27 \mu \mathrm{m}$, respectively. A thin layer of $\beta$-CuZn (thickness: $\sim 1 \mu \mathrm{m}$ ) emerged between the $\mathrm{CuZn}_{4}$ and the $\mathrm{Cu}$ substrate, as shown in Fig. 5 b), consistent with the results of a previous study [23]. In addition, numerous Kirkendall voids were also found at this $\mathrm{CuZn}_{4} / \mathrm{Cu}_{5} \mathrm{Zn}_{8}$ interface, which is in accordance with previous work on the $\mathrm{Zn}-\mathrm{Sn}-\mathrm{Cu}-\mathrm{Bi}$ solder system [24]. With the prolongation of the reflow duration with molten solder, the thickness of the $\mathrm{Cu}-\mathrm{Zn}$ IMCs continued to increase, to approximately $65 \mu \mathrm{m}$ after $15 \mathrm{~min}$ of reaction and $94 \mu \mathrm{m}$ after 30 min of reaction.

Notably, a few Kirkendall voids emerged near the $\mathrm{CuZn}$ interlayer (see the enlarged region in Fig. 5d)) in the $\mathrm{Zn}-5 \mathrm{Al} / \mathrm{Cu}$ solder interconnects after $30 \mathrm{~min}$ of reaction. This phenomenon has not previously been reported in $\mathrm{Zn}$-based solder joints, but it is similar to the observations of voids in $\mathrm{Cu}_{3} \mathrm{Sn}$ layers in aged $\mathrm{Sn} / \mathrm{Cu}$ solder joints $[12,25,26]$. The formation of these nano-sized voids can be attributed to the difference between the intrinsic diffusivities of $\mathrm{Cu}$ and $\mathrm{Zn}$. The $\mathrm{CuZn} /$ $\mathrm{Cu}$ and $\mathrm{Cu}_{5} \mathrm{Zn}_{8} / \mathrm{CuZn}$ interfaces served as locations for the agglomeration of defects into nano-/micro-voids (Kirkendall voids) near the interfaces. Such voids can seriously degrade the reliability of solder joints by acting as crack initiation regions when subjected to external loads [27]. Moreover, during service, these voids are likely to propagate with the growth of $\mathrm{CuZn}$ and aggregate to larger sizes, resulting in significant mechanical and electrical degradation of the solder joints $[28,29]$.

\subsection{IMC growth kinetics during liquid-solid reactions}

Fig. 6 shows the parabolic relationships between the thicknesses of all IMCs and the liquid-solid reaction durations for $\mathrm{Zn}-5 \mathrm{Al} / \mathrm{Cu}$ and $\mathrm{Zn}-5 \mathrm{Al} / \mathrm{Ni}-\mathrm{W}-\mathrm{P}$ interfaces reacted at $450{ }^{\circ} \mathrm{C}$ for $1,5,15$ and $30 \mathrm{~min}$. The thickness of the total $\mathrm{Cu}-\mathrm{Zn}$ IMC layer at the $\mathrm{Zn}-5 \mathrm{Al} / \mathrm{Cu}$ interface grew significantly, from approximately $17 \mu \mathrm{m}$ (after $1 \mathrm{~min}$ of reaction) to $94 \mu \mathrm{m}$ (after $30 \mathrm{~min}$ of reaction), as shown in Fig. 6 a), whereas the thickness of the $\mathrm{Al}_{3} \mathrm{Ni}_{2}$ at the $\mathrm{Zn}-5 \mathrm{Al} / \mathrm{Ni}-\mathrm{W}-\mathrm{P}$ interface grew only from $0.5 \mu \mathrm{m}$ (after $1 \mathrm{~min}$ of reaction) to $2.15 \mu \mathrm{m}$ (after 30 min of reaction). Fig. 6 b) shows the individual $\mathrm{Cu}-\mathrm{Zn}$ IMC thicknesses; the $\gamma-\mathrm{Cu}_{5} \mathrm{Zn}_{8}$ interlayer was the thickest among them, and the $\mathrm{CuZn}_{4}$ was the layer of intermediate thickness. Previous studies have reported that the rapid growth of $\mathrm{Cu}_{5} \mathrm{Zn}_{8}$ is a result of the high diffusion rates of $\mathrm{Cu}$ and $\mathrm{Zn}$ atoms in the $\mathrm{CuZn}_{4}$ phase [22,30]. By contrast, the growth rate of $\mathrm{CuZn}$ was the slowest among the three $\mathrm{Cu}-\mathrm{Zn}$ IMCs, with this layer reaching a maximum thickness of $2.5 \mu \mathrm{m}$ after

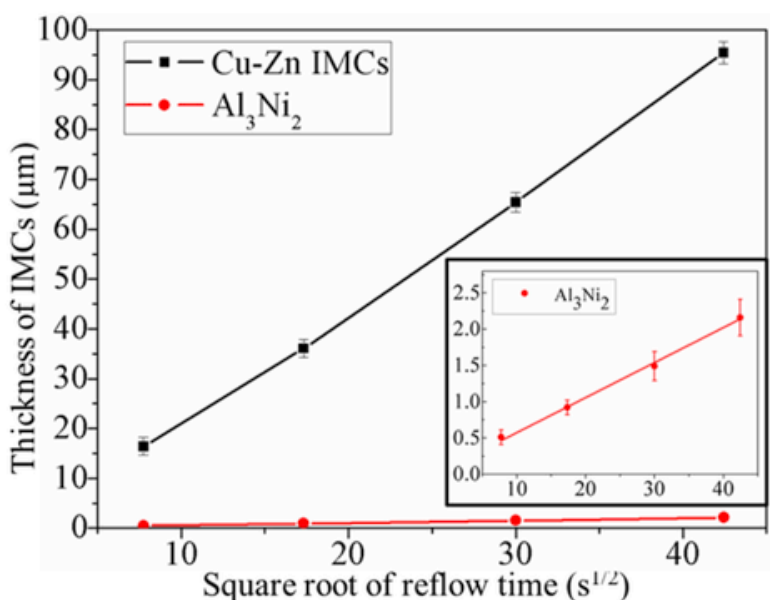

a)

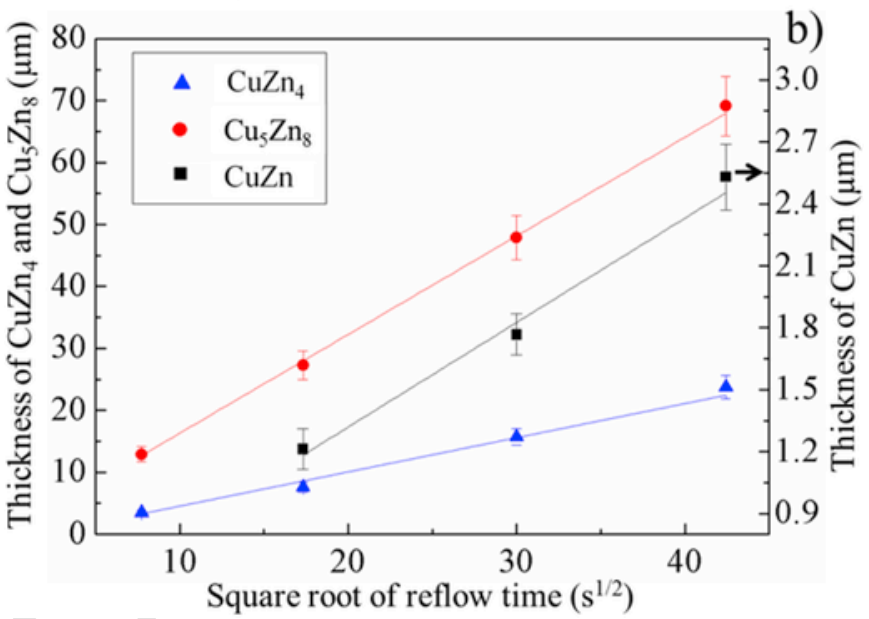

Fig. 6. Thicknesses of the $\mathrm{Zn}-\mathrm{Cu}$ IMCs formed after liquid-solid reaction at $450{ }^{\circ} \mathrm{C}$ for $1,5,15$ and $30 \mathrm{~min}$ at a) $\mathrm{Zn}-5 \mathrm{Al} / \mathrm{Cu}$ interfaces and b) $\mathrm{Zn}-5 \mathrm{Al} / \mathrm{Ni}-\mathrm{W}-\mathrm{P}$ interfaces.

$30 \mathrm{~min}$ of reaction. However, at the $\mathrm{Zn}-5 \mathrm{Al} / \mathrm{Ni}-\mathrm{W}-\mathrm{P}$ solder interface after 30 min of reaction, the growth rate of $\mathrm{Al}_{3} \mathrm{Ni}_{2}$ was even slower than that of $\mathrm{CuZn}$, which was the slowest IMC to form at the $\mathrm{Zn}-5 \mathrm{Al}$ / $\mathrm{Cu}$ solder interface.

Generally, it was clearly observed that the IMC thickness (d) increased linearly with the square root of t. This linear relationship indicates that the growth mechanisms of all IMCs were diffusion-controlled, consistent with the following parabolic law:

$$
d=k \sqrt{t}
$$

where $\mathrm{d}$ is the thickness of the IMC layer, $\mathrm{t}$ is the liquid-solid reaction duration, and $\mathrm{k}$ is the growth rate coefficient for the IMC of interest, which can be calculated for each IMC from the slope of the corresponding fit line in Fig. 6.

In this way, the experimental values of $\mathrm{k}$ for the different interfacial IMCs that form in $\mathrm{Zn}-\mathrm{Al}$ solder interconnects under harsh conditions were calculated and are listed in Table 2.

For the $\mathrm{Zn}-5 \mathrm{Al}$ solder interconnects with Ni-W-P coatings, the growth rate coefficient $(\mathrm{k})$ of the $\mathrm{Al}_{3} \mathrm{Ni}_{2}$ layer was $4.9 \times 10^{-2} \mu \mathrm{m} /$ $\mathrm{s}^{1 / 2}$ because of the slow reaction rate between the molten $\mathrm{Zn}-5 \mathrm{Al}$ solder and the Ni-W-P coating. During the initial liquid-solid reaction (1 min), a good metallurgical and electrical bond was achieved through a thin $\mathrm{Al}_{3} \mathrm{Ni}_{2}$ layer with a reasonable thickness $(\sim 0.5 \mu \mathrm{m})$. 
Table 2

Comparison of the formation and growth of IMCs at $\mathrm{Zn}-5 \mathrm{Al} / \mathrm{Ni}-\mathrm{W}-\mathrm{P}$ and $\mathrm{Zn}-5 \mathrm{Al} / \mathrm{Cu}$ interconnects during liquid-solid reactions.

\begin{tabular}{llll}
\hline Solder interconnect & $\mathrm{IMC}$ & $k\left(\mu \mathrm{m} / \mathrm{s}^{1 / 2}\right)$ & Reflow temperature $\left({ }^{\circ} \mathrm{C}\right)$ \\
\hline $\mathrm{Zn}-5 \mathrm{Al} / \mathrm{Ni}-\mathrm{W}-\mathrm{P}$ & $\mathrm{Al}_{3} \mathrm{Ni}_{2}$ & $4.90 \times 10^{-2}$ & 450 \\
$\mathrm{Zn}-5 \mathrm{Al} / \mathrm{Cu}$ & $\mathrm{Cu}-\mathrm{Zn} \mathrm{IMCs}$ & 2.180 & 450 \\
& $\varepsilon-\mathrm{CuZn}{ }_{4}$ & $5.506 \times 10^{-1}$ & 450 \\
& $\gamma-\mathrm{Cu}_{5} \mathrm{Zn}_{8}$ & 1.573 & 450 \\
& $\beta-\mathrm{CuZn}$ & $5.607 \times 10^{-2}$ & 450 \\
\hline
\end{tabular}

Even after 30 min of reaction, the average thickness of the $\mathrm{Al}_{3} \mathrm{Ni}_{2}$ was approximately $2.1 \mu \mathrm{m}$, which is still a reasonable thickness for interfacial IMC layers [31]. It is widely known that excessive growth of IMCs has a tendency to cause the mechanical reliability of solder joints to deteriorate. Therefore, this slow growth rate of $\mathrm{Al}_{3} \mathrm{Ni}_{2}$ is regarded as beneficial for the reliability of solder joints.

The overall growth rate coefficient for all $\mathrm{Cu}-\mathrm{Zn}$ IMCs was $2.18 \mu \mathrm{m} / \mathrm{s}^{1 / 2}$, nearly 44 times higher than that for the $\mathrm{Al}_{3} \mathrm{Ni}_{2}$ in the $\mathrm{Zn}-5 \mathrm{Al} / \mathrm{Ni}-\mathrm{W}-\mathrm{P} / \mathrm{Cu}$ interconnects. Regarding the individual $\mathrm{Cu}-\mathrm{Zn}$ IMCs, the growth rate coefficients $(k)$ of $\gamma-\mathrm{Cu}_{5} \mathrm{Zn}_{8}$ and $\varepsilon-\mathrm{CuZn} \mathrm{n}_{4}$ were $1.573 \mu \mathrm{m} / \mathrm{s}^{1 / 2}$ and $0.551 \mu \mathrm{m} / \mathrm{s}^{1 / 2}$, respectively, whereas the $\mathrm{k}$ value for the $\beta-\mathrm{CuZn}$ interlayer was the smallest at only $5.607 \times 10^{-2} \mu \mathrm{m} / \mathrm{s}^{1 / 2}$.

\subsection{Diffusional formation mechanism of IMCs in Zn-Al solder interconnects}

Based on the results discussed above, Fig. 7 schematically illustrates the diffusional formation mechanisms of the interfacial IMCs at $\mathrm{Zn}-\mathrm{Al}$ solder interconnects. During the liquid-solid reactions at the $\mathrm{Zn}-\mathrm{Al} / \mathrm{Cu}$ interfaces, the $\mathrm{Zn}-5 \mathrm{Al}$ solder was in a liquidus state while the $\mathrm{Cu}$ remained solid. $\mathrm{Zn}$ atoms were abundant because of the fast diffusion rate in liquid. As a result, $\mathrm{CuZn}_{4}$, a $\mathrm{Zn}$-enriched phase, formed first. The mutual diffusion and reaction of these two elements were driven by the differences in concentration between the solder and the substrate matrix. By virtue of the high diffusion rates of $\mathrm{Cu}$ and $\mathrm{Zn}$ atoms in $\mathrm{CuZn}_{4}$ layers, as reported by Gancarz and Xiao et al. [22,30], $\mathrm{Cu}_{5} \mathrm{Zn}_{8}$ could rapidly grow to form into the thickest layer among the various $\mathrm{Cu}-\mathrm{Zn}$ IMC layers. The faster diffusion rate of the $\mathrm{Zn}$ element also triggered a vacancy flux in the opposite direction, generating vacancies in the $\mathrm{CuZn}_{4}$ near the $\mathrm{Cu}_{5} \mathrm{Zn}_{8}$ phase. Then, these vacancies accumulated to form Kirkendall voids, as illustrated in Fig. 7 a). A similar phenomenon also occurs in $\mathrm{Zn}-\mathrm{Sn}-\mathrm{Cu}-\mathrm{Bi} / \mathrm{Cu}$ solder joints after $90 \mathrm{~s}$ of liquid reaction [24]. Afterwards, $\mathrm{Zn}$ atoms in the $\mathrm{Cu}_{5} \mathrm{Zn}_{8}$ phase slowly reacted with $\mathrm{Cu}$ atoms from the substrate to form a $\mathrm{CuZn}$ phase as the liquid-solid reaction continued. Thus, the enormous difference in the growth rates of the $\mathrm{Cu}_{5} \mathrm{Zn}_{8}$ and $\mathrm{CuZn}$ phases contributed to the unbalanced interdiffusion of the $\mathrm{Cu}$ and $\mathrm{Zn}$ elements. Consequently, the formation of Kirkendall voids near the $\mathrm{CuZn}$ layer is clearly unavoidable. This situation has seldom been previously reported in $\mathrm{Zn}-\mathrm{Al}$ solder joints, but enormous efforts have been made with regard to conventional Sn-based solder joints, with similar findings concerning void formation in $\mathrm{Cu}_{3} \mathrm{Sn}$ layers $[12,25,26]$. Based on these works, it can be predicted that these Kirkendall voids in $\mathrm{Zn}-\mathrm{Al}$ solder joints could cause the mechanical reliability of $\mathrm{Zn}-\mathrm{Al}$ solder joints to deteriorate. Overall, the interfacial reaction in a $\mathrm{Zn}-\mathrm{Al}$ solder interconnect without a diffusion barrier is rather complex and accompanied by the formation of various defects, as illustrated in Fig. 7 a).

By contrast, when an electroless Ni-W-P coating was employed as a diffusion barrier, only $\mathrm{Ni}$ atoms diffused out from the metallisation and then reacted with $\mathrm{Al}$ atoms from the solder matrix to form a relatively thin $\mathrm{Al}_{3} \mathrm{Ni}_{2}$ layer ( $2.15 \mu \mathrm{m}$ after $30 \mathrm{~min}$ of reaction), according to the elemental analysis (see Fig. 5). The continuous growth of this thin $\mathrm{Al}_{3} \mathrm{Ni}_{2}$ IMC layer attracted $\mathrm{Al}$ and $\mathrm{Ni}$ atoms as they slowly diffused from the solder and the coating matrix, respectively. By preventing the formation of different types of IMCs, the formation of micro-sized Kirkendall voids near the $\mathrm{Zn}-5 \mathrm{Al} / \mathrm{Ni}-\mathrm{W}-\mathrm{P}$ interface after liquid-solid reaction for up to $30 \mathrm{~min}$ could thus be avoided.

\section{Conclusions}

This study investigated the effects of electroless Ni-W-P coating as a diffusion barrier in high-temperature $\mathrm{Zn}-5 \mathrm{Al}$ solder joints. The interfacial reaction between the molten $\mathrm{Zn}-5 \mathrm{Al}$ solder and the electroless $\mathrm{Ni}-\mathrm{W}-\mathrm{P}$ coating was investigated, and $\mathrm{Zn}-5 \mathrm{Al} / \mathrm{Cu}$ interconnects under the same reflow conditions were tested for comparison. The following conclusions can be drawn:

1. The presence of an electroless Ni-W-P coating can significantly decrease the thickness of the interfacial IMC layer that forms from $94 \mu \mathrm{m} \quad(\mathrm{Cu}$ substrate, $30 \mathrm{~min}$ of reaction $)$ to $2.15 \mu \mathrm{m}$ (Ni-W-P-coated $\mathrm{Cu}$ substrate, 30 min of reaction), which demonstrates the excellent diffusion barrier property of electroless $\mathrm{Ni}-\mathrm{W}-\mathrm{P}$ coatings for preventing reactions between $\mathrm{Zn}-5 \mathrm{Al}$ solder and $\mathrm{Cu}$.

2. At a $\mathrm{Zn}-5 \mathrm{Al} / \mathrm{Cu}$ interface, three types of IMCs, namely, $\mathrm{CuZn}_{4}$, $\mathrm{Cu}_{5} \mathrm{Zn}_{8}$ and $\mathrm{CuZn}$, can be identified, and the overall growth rate coefficient for all IMCs is $2.18 \mu \mathrm{m} / \mathrm{s}^{1 / 2}$. By contrast, when an electroless Ni-W-P coating is applied, the growth rate coefficient of the resulting $\mathrm{Al}_{3} \mathrm{Ni}_{2}$ layer is significantly lower $\left(4.90 \times 10^{-2} \mu \mathrm{m} / \mathrm{s}^{1 / 2}\right)$.

3. The interlayer at a $\mathrm{Zn}-5 \mathrm{Al} / \mathrm{Ni}-\mathrm{W}-\mathrm{P}$ interface remains intact after liquid-solid reaction for a duration of $30 \mathrm{~min}$. By contrast, a notable number of Kirkendall voids can be found at the
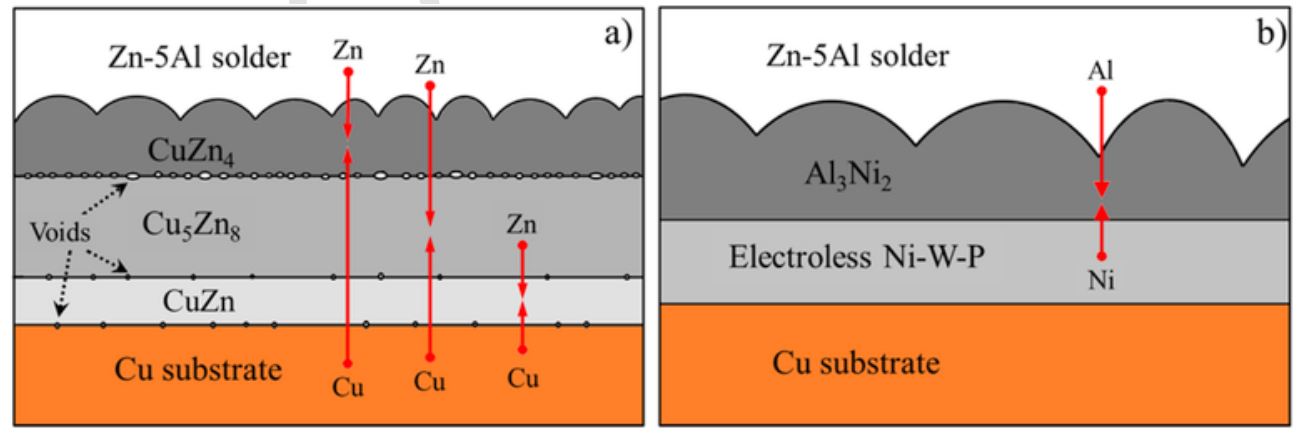

Fig. 7. Schematic diagrams illustrating the diffusional formation mechanisms at a) a $\mathrm{Zn}-5 \mathrm{Al} / \mathrm{Cu}$ interface and b) a $\mathrm{Zn}-5 \mathrm{Al} / \mathrm{Ni}-\mathrm{W}-\mathrm{P}$ interface. 
$\mathrm{CuZn} n_{4} / \mathrm{Cu}_{5} \mathrm{Zn}_{8}, \mathrm{Cu}_{5} \mathrm{Zn}_{8} / \mathrm{CuZn}$ and $\mathrm{CuZn} / \mathrm{Cu}$ interfaces in $\mathrm{Zn}-5 \mathrm{Al} /$ $\mathrm{Cu}$ solder joints after prolonged reaction.

4. During liquid-solid reaction, the thickness of the IMC layer follows a parabolic law with respect to the reaction duration in both $\mathrm{Zn}-5 \mathrm{Al} / \mathrm{Cu}$ and $\mathrm{Zn}-5 \mathrm{Al} / \mathrm{Ni}-\mathrm{W}-\mathrm{P} / \mathrm{Cu}$ interconnects. This finding indicates that the growth mechanism of the IMC layers is diffusion-controlled.

\section{Acknowledgements}

This research was supported by a Marie Curie International Research Staff Exchange Scheme Project within the 7th European Community Framework Programme, No. PIRSES-GA-2010-269113, entitled "Micro-Multi-Material Manufacture to Enable Multifunctional Miniaturised Devices (M6)", as well as an EPSRC-CPB Funding (GRANT NO. FS14). The authors also acknowledge the research funding by the National Nature Science Foundation of China (NSFC GRANT NO. 61261160498).

\section{References}

[1] S. Menon, E. George, M. Osterman, M. Pecht, High lead solder (over 85\%) solder in the electronics industry: RoHS exemptions and alternatives, J. Mater. Sci. Mater. Electron. 26 (No. 6) (2015) 4021-4030.

[2] V.R. Manikam, K.Y. Cheong, Die attach materials for high temperature applications: a review, IEEE Trans. Compon. Packag. Manuf. Technol. 1 (No. 4) (2011) 457-478.

[3] Vivek Chidambaram, John Hald, Jesper Hattel, Development of Au-Ge based candidate alloys as an alternative to high-lead content solders, J. Alloys Compd. 490 (2010) 170-179.

[4] R. Koleňák, M. Chachula, Characteristics and properties of Bi-11Ag solder, Solder. Surf. Mt. Technol. 25 (No. 2) (2013) 68-75.

[5] T. Youssef, W. Rmili, E. Woirgard, S. Azzopardi, N. Vivet, et al., Power modules die attach: a comprehensive evolution of the nanosilver sintering physical properties versus its porosity, Microelectron. Reliab. 55 (No. 9-10) (2015) 1997-2002.

[6] M.S. Kim, H. Nishikawa, Effects of bonding temperature on microstructure, fracture behavior and joint strength of Ag nanoporous bonding for high temperature die attach, Mater. Sci. Eng. A 645 (2015) 264-272.

[7] A. Haque, B.H. Lim, A.S.M.A. Haseeb, H.H. Masjuki, Die attach properties of $\mathrm{Zn}-\mathrm{Al}-\mathrm{Mg}-\mathrm{Ga}$ based high-temperature lead-free solder on $\mathrm{Cu}$ lead-frame, J. Mater. Sci. Mater. Electron. 23 (2012) 115-123.

[8] Tomasz Gancarz, Janusz Pstruś, Przemysław Fima, Sylwia Mosińska, Thermal properties and wetting behavior of high temperature Zn-Al-In solders, J. Mater. Eng. Perform. 21 (2012) 599-605.

[9] Yoshikazu Takaku, Lazuardi Felicia, Ikuo Ohnuma, Ryosuke Kainuma, Kiyohito Ishida, Interfacial reaction between $\mathrm{Cu}$ substrates and $\mathrm{Zn}-\mathrm{Al}$ base high-temperature Pb-Free solders, J. Electron. Mater. 37 (2008) 314-323.

[10] Min He, Zhong Chen, Guojun Qi, Mechanical strength of thermally aged Sn-3.5Ag/Ni-P solder joints, Metall. Mater. Trans. A 36 (2005) 65-75.

[11] V. Vuorinen, T. Laurila, H. Yu, J.K. Kivilahti, Phase formation between lead-free $\mathrm{Sn}-\mathrm{Ag}-\mathrm{Cu}$ solder and $\mathrm{Ni}(\mathrm{P})$ Au finishes, J. Appl. Phys. 99 (2006) 023530 .

[12] K. Chen, C. Liu, D.C. Whalley, D.A. Hutt, J.F. Li, S.H. Mannan, A comparative study of the interfacial reaction between electroless $\mathrm{Ni}-\mathrm{P}$ coatings and molten tin, Acta Mater. 56 (2008) 5668-5676.
[13] S.K. Tien, J.G. Duh, Y.I. Chen, Structure, thermal stability and mechanical properties of electroless Ni-P-W alloy coatings during cycle test, Surf. Coat. Technol. 177-178 (2004) 532-536.

[14] J.N. Balaraju, Kalavati, N.T. Manikandanath, V.K. William Grips, Phase transformation behavior of nanocrystalline $\mathrm{Ni}-\mathrm{W}-\mathrm{P}$ alloys containing various $\mathrm{W}$ and P contents, Surf. Coat. Technol. 206 (2012) 2682-2689.

[15] Dong Min Jang, Jin Yu, Tungsten alloying of the Ni(P) films and the reliability of Sn-3.5Ag/NiWP solder joints, J. Mater. Res. 26 (2011) 889-895.

[16] Ying Yang, J.N. Balaraju, Ser Choong Chong, Hui Xu, Changqing Liu, Vadim V. Silberschmidt, Zhong Chen, Significantly retarded interfacial reaction between an electroless $\mathrm{Ni}-\mathrm{W}-\mathrm{P}$ metallization and lead-free $\mathrm{Sn}-3.5 \mathrm{Ag}$ solder, J. Alloys Compd. 565 (2013) 11-16.

[17] K. Chen, C. Liu, D.C. Whalley, D.A. Hutt, Electroless Ni-W-P alloys as barrier coating s for liquid solder interconnects, In: 1st Electronics System Integration Technology Conference (ESTC), Dresden, Germany, 2006, pp. 421-427.

[18] Yoshikazu Takaku, Komei Makino, Keita Watanabe, Ikuo Ohnuma, Ryosuke Kainuma, Yasushi Yamada, Yuji Yagi, Ikuo Nakagawa, Takashi Atsumi, Kiyohito Ishida, Interfacial reaction between $\mathrm{Zn}$-Al-Based high-temperature solders and Ni substrate, J. Electron. Mater. 38 (2009) 54-60.

[19] F.X. Che, John H.L. Pang, Characterization of IMC layer and its effect on thermomechanical fatigue life of $\mathrm{Sn}-3.8 \mathrm{Ag}-0.7 \mathrm{Cu}$ solder joints, J. Alloys Compd. 541 (2012) 6-13.

[20] W.H. Chen, C.F. Yu, H.C. Cheng, Y.M. Tsai, S.T. Lu, IMC growth reaction and its effects on solder joints thermal cycling reliability of 3D chip stacking packaging, Microelectron. Reliab. 53 (2013) 30-40.

[21] H.B. Qin, W.Y. Li, W.B. Zhou, X.P. Zhang, Low cycle fatigue performance of ball grid array structure $\mathrm{Cu} / \mathrm{Sn}-3.0 \mathrm{Ag}-0.5 \mathrm{Cu} / \mathrm{Cu}$ solder joints, Microelectron. Reliab. 54 (2014) 2911-2921.

[22] Tomasz Gancarz, Janusz Pstruś, Przemysław Fima, Sylwia Mosińska, Effect of $\mathrm{Ag}$ addition to $\mathrm{Zn}-12 \mathrm{Al}$ alloy on kinetics of growth of intermediate phases on Cu substrate, J. Alloys Compd. 582 (2014) 313-322.

[23] K. Suganuma, T. Murata, H. Noguchi, Y. Toyada, Heat resistance of Sn-9Zn solder/Cu interface with or without coating, J. Mater. Res. 15 (No.4) (2000) 884-891.

[24] Fei Xing, Jia Yao, Jingwei Liang, Xiaoming Qiu, Influence of intermetallic growth on the mechanical properties of $\mathrm{Zn}-\mathrm{Sn}-\mathrm{Cu}-\mathrm{Bi} / \mathrm{Cu}$ solder joints, J. Alloys Compd. 649 (2015) 1053-1059.

[25] Glenn Ross, Vesa Vuorinen, Mervi Paulasto-Kröckel, Void formation and its impact on $\mathrm{Cu} \mathrm{Sn}$ intermetallic compound formation, J. Alloys Compd. 677 (2016) 127-138.

[26] Qingqian $\mathrm{Li}$, Y.C. Chan, Growth kinetics of the $\mathrm{Cu}_{3} \mathrm{Sn}$ phase and void formation of sub-micrometre solder layers in $\mathrm{Sn}-\mathrm{Cu}$ binary and $\mathrm{Cu}-\mathrm{Sn}-\mathrm{Cu}$ sandwich structures, J. Alloys Compd. 567 (2013) 47-53.

[27] Cheng En Ho, Tsai Tung Kuo, Chun Chien Wang, Wei Hsiang Wu, Inhibiting the growth of $\mathrm{Cu} 3 \mathrm{Sn}$ and Kirkendall voids in the $\mathrm{Cu} / \mathrm{Sn}-\mathrm{Ag}-\mathrm{Cu}$ system by minor Pd alloying, Electron. Mater. Lett. 8 (2012) 495-501.

[28] K. Zeng, R. Stierman, T.C. Chiu, D. Edwards, K. Ano, K.N. Tu, Kirkendall void formation in eutectic $\mathrm{SnPb}$ solder joints on bare $\mathrm{Cu}$ and its effect on joint reliability, J. Appl. Phys. 97 (2005). 024508-1-8.

[29] Jin Yu, J.Y. Kim, Effects of residual S on Kirkendall void formation at $\mathrm{Cu}$ / Sn-3.5Ag solder joints, Acta Mater. 56 (2008) 5514-5523.

[30] Yong Xiao, Mingyu Li, Ling Wang, Shangyu Huang, Xueming Du, Zhiquan Liu, Interfacial reaction behavior and mechanical properties of ultrasonically brazed $\mathrm{Cu} / \mathrm{Zn}-\mathrm{Al} / \mathrm{Cu}$ joints, Mater. Des. 73 (2015) 42-49.

[31] P. Xue, B.L. Xiao, D.R. Ni, Z.Y. Ma, Enhanced mechanical properties of friction stir welded dissimilar Al-Cu joint by intermetallic compounds, Mater. Sci. Eng. A 527 (2010) 5723-5727. 